\title{
Structural rearrangement of the actin cytoskeleton in regenerating protoplasts of budding yeasts
}

\author{
Miroslav Gabriel, ${ }^{*}$ Marie Kopecká and Augustin Svoboda \\ Department of Biology, Faculty of Medicine, Masaryk University, 66243 Brno, Czechoslovakia
}

(Received 3 March 1992; accepted 24 June 1992)

\begin{abstract}
In Saccharomyces cerevisiae cells the actin cytoskeleton is present as actin dots in the bud and around the septum, i.e. in areas of intensive cell wall synthesis, and as actin cables, which are loose bundles along the longitudinal cell axis. However, the apparently asymmetrical pattern of actin no longer persisted after protoplasting, when the cables disappeared and dots were evenly distributed under the whole protoplast surface. This pattern was maintained during regeneration of a new cell wall all over the protoplast surface, thus providing evidence of a relationship between the new wall formation and the presence of a regular arrangement of actin dots. The completed cell wall allowed the protoplast to bud and produce a normal daughter cell. However, before the walled protoplast began to bud, actin dots accumulated at the site of bud emergence and actin cables appeared, extending to the cytoplasm. Later, actin dots accumulated in the growing bud, forming a ring in the neck, and actin cables passed to the bud. Completion of the protoplast-to-cell reversion was preceded by restoration of the normal actin cytoskeleton.
\end{abstract}

\section{Introduction}

The molecular mechanisms involved in control of budding morphogenesis in the yeast Saccharomyces cerevisiae have attracted increasing attention (Drubin, 1991). Information has accumulated suggesting that the key role in the morphogenesis of yeasts is played by the actin cytoskeleton together with a variety of associated proteins. This notion is evidenced for instance by dynamic changes in actin distribution during the cell cycle (Kilmartin \& Adams, 1984; Adams \& Pringle, 1984), by aberrant morphogenesis found in temperaturesensitive actin mutants (Novick \& Botstein, 1985), and in strains carrying mutations in genes for capping protein (Amatruda et al., 1990), profiline (Haarer et al., 1990), tropomyosin (Liu \& Bretscher, 1989), the actinassociated $67 \mathrm{kDa}$ (Adams et al., 1989) and $85 \mathrm{kDa}$ proteins (Drubin et al., 1988), and the myosin MYO2 gene (Johnston et al., 1991). All these mutants show the loss of asymmetric distribution of actin, including disappearance of actin cables. In these mutants the aberrant phenotypes are an irreversible consequence of mutation in the given genes. However, we have demonstrated that a similar loss of the asymmetric distribution of the actin cytoskeleton can be achieved by protoplasting of the cell (unpublished observations).

\footnotetext{
* Author for correspondence. Fax 42526606.
}

Since under certain conditions protoplasts can regenerate their cell walls and produce new cells (Nečas \& Svoboda, 1981, 1985) it is assumed that the defects in the actin cytoskeleton induced by protoplasting will be reversible. Repair of the actin cytoskeleton in relation to regeneration of the cell wall and renewal of cell morphogenesis is described in this paper.

\section{Methods}

Strain. The strain used was Saccharomyces cerevisiae DBY 1690 , genotype $M A T \alpha / M A T \mathbf{a}$, ade2-1+, with the standard actin allele $A C T 1+\mid A C T 1+$ from a collection of temperature-sensitive yeast actin mutants (Novick \& Botstein, 1985) which was kindly provided by Professor David Botstein of MIT, Cambridge, USA.

Media. Cells for actin skeleton studies were incubated in YEPD medium, comprising (w/v) $1 \%$ yeast extract, $2 \%$ bactopeptone and $2 \%$ glucose (Novick \& Botstein, 1985). To prepare protoplasts, cells were grown in malt extract medium, pH 5.5 , at $23^{\circ} \mathrm{C}$. Protoplasts were regenerated in a $1: 1(\mathrm{v} / \mathrm{v})$ mixture of YEPD and $\mathrm{N} 1$ medium $(5 \mathrm{~g}$ glucose, $1.25 \mathrm{~g}$ asparagine, $1.25 \mathrm{~g} \mathrm{KH}_{2} \mathrm{PO}_{4}, 0.425 \mathrm{~g} \mathrm{MgSO}_{4} .7 \mathrm{H}_{2} \mathrm{O}$, $50 \mathrm{ml}$ distilled water; Kelleti et al., 1954). Osmotic stabilization was achieved with $0.8 \mathrm{M}$-mannitol. Solid media contained $30 \%(\mathrm{w} / \mathrm{v})$ gelatin dissolved in YEPD-N1 medium.

Protoplast preparation. Cells growing in malt extract medium were collected in the exponential phase, washed twice by centrifugation with distilled water and exposed to snail enzyme medium $(10 \% \mathrm{w} / \mathrm{v}$, snail enzyme, $0.8 \mathrm{M}$-mannitol, citrate/phosphate buffer, $\mathrm{pH} 5.6$, with $0.01 \mathrm{M}$ $\mathrm{MgSO}_{4}$ ) for 60 to $120 \mathrm{~min}$ at $23^{\circ} \mathrm{C}$. Protoplasts were harvested and 

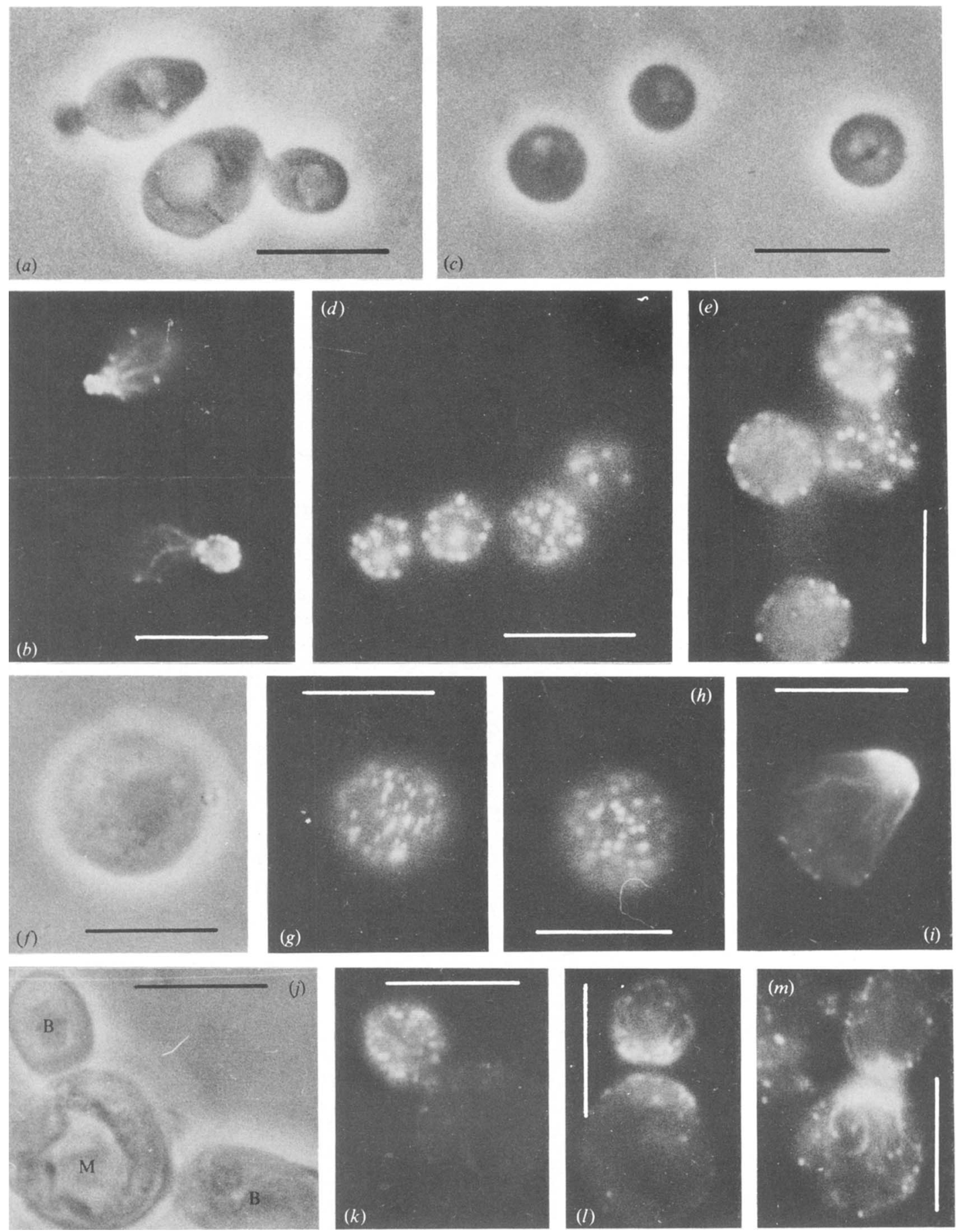

Fig. 1. Micrographs of the DBY $1690 A C T 1+\mid A C T 1+$ cells and their protoplasts. (a) Cells growing in YEPD medium at $23^{\circ} \mathrm{C}$. Phasecontrast microscopy. (b) Localization of actin in cells fixed in YEPD medium and stained with rhodamine phalloidin. While cytoplasmic actin cables are typical for parental cells, actin dots are concentrated in buds and their necks. Fluorescence microscopy. (c) Protoplasts freshly prepared with $10 \%$ snail enzyme, osmotically stabilized with $0.8 \mathrm{M}$-mannitol in citrate/phosphate buffer, $\mathrm{pH} 5.5$, with $0.01 \mathrm{M}-\mathrm{MgSO}_{4}$. Phase-contrast microscopy. $(d)$ Localization of actin in protoplasts fixed in osmotic stabilizer and stained with rhodamine phalloidin. Only actin dots are visualized under the protoplast surfaces. No actin cables are present. Fluorescence microscopy. (e) Rhodamine phalloidin stained, fixed protoplasts after $2 \mathrm{~h}$ of regeneration in gelatin at $23^{\circ} \mathrm{C}$. These protoplasts are larger than the fresh ones and the only detectable surface structures are actin dots. Fluorescence microscopy. $(f)$ Protoplasts after $5 \mathrm{~h}$ regeneration in gelatin. The spherical shape is still preserved. Phase-contrast microscopy. ( $g$ ) Actin localization in a fixed protoplast after $5 \mathrm{~h}$ regeneration in gelatin, stained with rhodamine phalloidin. Actin dots are distributed over the surface; no cytoplasmic cables can be seen. Fluorescence microscopy. $(h)$ Actin dots are the only detectable structures in a protoplast cultured in regeneration medium for $19 \mathrm{~h}$ at $23^{\circ} \mathrm{C}$ and, after fixation, stained with rhodamine phalloidin. Fluorescence microscopy. (i) A protoplast from the $19 \mathrm{~h}$ culture 
washed twice by centrifugation at $670 \mathrm{~g}$ for $6 \mathrm{~min}$ with osmotic stabilizer.

Protoplast regeneration. Protoplasts were allowed to regenerate cell walls in $30 \%(\mathrm{w} / \mathrm{v})$ gelatin (Nečas, 1961) dissolved in regeneration medium osmotically stabilized with $0.8 \mathrm{M}$-mannitol. A $0.1 \mathrm{ml}$ suspension of protoplasts $\left(6 \times 10^{7} \mathrm{ml}^{-1}\right)$ in osmotic stabilizer was stirred with $2 \mathrm{ml}$ gelatin medium melted at $37^{\circ} \mathrm{C}$ in a water bath (manipulation at $37^{\circ} \mathrm{C}$ did not exceed $30 \mathrm{~s}$ ). The tubes were taken out of the bath and gelatin with protoplasts was spread into a thin coat on the inside walls using sterile glass rods. The protoplasts were grown at $23^{\circ} \mathrm{C}$.

Isolation of regenerating and regenerated protoplasts from gelatin. The regeneration medium, enriched with $0.8 \mathrm{M}$-mannitol and $5 \mathrm{ml} 0.6 \mathrm{M}$ $\mathrm{KCl}, \mathrm{pH} 5 \cdot 5$, warmed to $37^{\circ} \mathrm{C}$, was added to the tubes with protoplasts embedded in gelatin. Gentle stirring helped to dissolve the gelatin in 2 to $5 \mathrm{~min}$. Protoplasts were purified by centrifugation in regeneration medium with mannitol for $6 \mathrm{~min}$ at $670 \mathrm{~g}$ at $37^{\circ} \mathrm{C}$, which was repeated two or three times.

Fixation of specimens. Cells were fixed in YEPD medium, fresh protoplasts in osmotic stabilizer, and regenerating protoplasts and revertants in the regeneration medium according to Pringle et al. (1989) supplemented with $20 \mathrm{~mm}-\mathrm{MgCl}_{2}$ and $10 \mathrm{~mm}$-EGTA. Fixation took place at room temperature for $90 \mathrm{~min}$. Before visualization the specimens were washed three times with phosphate buffer at $\mathrm{pH} 6.9$.

Rhodamine phalloidin staining. Actin was labelled with rhodamine phalloidin R-415 (Molecular Probes, Inc.) by the method of Pringle et al. (1989). After staining for 30 to $60 \mathrm{~min}$, the specimens were washed five times with phosphate-buffered saline and placed on grease-free slides. Dried slides were mounted in $p$-phenylenediamine in $90 \%(\mathrm{v} / \mathrm{v})$ glycerol ( $\mathrm{pH} 9.0)$. All the phases of staining were performed under red light.

Phase-contrast and fuorescence microscopy. Cells, protoplasts and fixed specimens were examined by phase-contrast microscopy (Amplival, Zeiss Jena; magnification $\times 320$ ) and by fluorescence microscopy (Jenalumar, set of filters, 4-4-, G 263, 570; magnification $\times 320$ ). For photography, Svema 19 DIN film was used at an exposure of $4 \mathrm{~min}$.

Electron Microscopy. (i) Freeze-etching. Replicas were prepared from protoplasts isolated from gelatin after 5 and $19 \mathrm{~h}$ of regeneration. A suspension of viable protoplasts in regeneration medium was frozen in Freon 22 and liquid nitrogen and processed in a BA $360 \mathrm{M}$ Balzers apparatus (Moor \& Muhlethaler, 1963), and replicas photographed in a Tesla BS 500 electron microscope.

(ii) Platinum-shadowed preparations. Protoplasts isolated after $2 \mathrm{~h}$, $5 \mathrm{~h}$ and $19 \mathrm{~h}$ of regeneration in gelatin were washed with nutrient medium, pelleted, and $0.5 \%$ sodium dodecyl sulphate was added. The protoplasts were allowed to stand for $10 \mathrm{~min}$ at $50^{\circ} \mathrm{C}$ (Kopecká \& Kreger, 1986). After three washes with distilled water, the specimens were placed in Formvar-coated grids, shadowed with platinum and photographed in a Tesla BS 500 electron microscope.

\section{Results}

\section{Actin cytoskeleton in cells}

The distribution of fluorescent actin structures in the cells of $S$. cerevisiae DBY 1690 was analogous to that described by Novick \& Botstein (1985). Budless cells $\left(G_{1}\right)$ contained either cortical actin dots distributed randomly under the surface or actin dots, in some cases attached to actin cables, arranged in a ring indicating the site of bud emergence and chitin localization (Kilmartin \& Adams, 1984). In budding cells, actin dots were also accumulated in the bud and cytoplasmic actin cables stretched from cell to bud along the longitudinal axis (Fig. 1b). During cytokinesis the dots moved to the septum region.

\section{Actin cytoskeleton in fresh protoplasts}

After removal of the cell wall, oval cells (Fig. $1 a$ ) turned into isodiametric protoplasts (Fig. 1c). They contained only actin dots, while the cytoplasmic actin cables typical of parental cells (Fig. 1 b) disappeared or were only present on rare occasions. The even distribution of dots at the protoplast surface was a regular finding (Fig. $1 d$ ).

\section{Actin cytoskeleton in regenerating protoplasts}

To analyse the behaviour of the actin cytoskeleton during regeneration, protoplasts were embedded in a gelatin regeneration medium (Nečas \& Svoboda, 1985) and at intervals were isolated for examination.

Protoplasts isolated at $2 \mathrm{~h}$ were larger than the freshly prepared ones but still maintained their isodiametric shape. The actin dots near the surface of the regenerating protoplasts were randomly distributed (Fig. 1e). In the cytoplasm, actin cables were either absent or difficult to discern. Electron microscopy showed a thin cell wall layer consisting of fibrils partially masked with amorphous matrix (not shown).

Protoplasts that had regenerated for $5 \mathrm{~h}$ still had a spherical shape (Fig. $1 f$ ); they were covered with rather thick cell walls with smooth surfaces, indicating the

stained, after fixation, with rhodamine phalloidin. Actin dots are accumulated in a patch (upper right) while the other parts of the protoplast surface are almost free of actin dots. Actin cables extend toward the site of bud emergence. ( $j$ ) Protoplast with regenerated cell wall (M) reverting to cells (B) after $19 \mathrm{~h}$ cultivation. Phase-contrast microscopy. $(k)$ A revertant fixed after $19 \mathrm{~h}$ cultivation in gelatin at $23{ }^{\circ} \mathrm{C}$. The view is focussed on actin dots concentrated in the bud and mostly absent in the cell, which contains some actin cables. Fluorescence microscopy. (l) A revertant after $19 \mathrm{~h}$ regeneration. The view is focussed on the septum area with a high density of actin dots. $(m)$ A revertant with numerous actin cables following the protoplast perimeter and extending to the bud. The view is focussed on the protoplast surface near the septum region showing the highest concentration of actin dots. Fluorescence microscopy. Bars, $10 \mu \mathrm{m}$ $(a-m)$. 


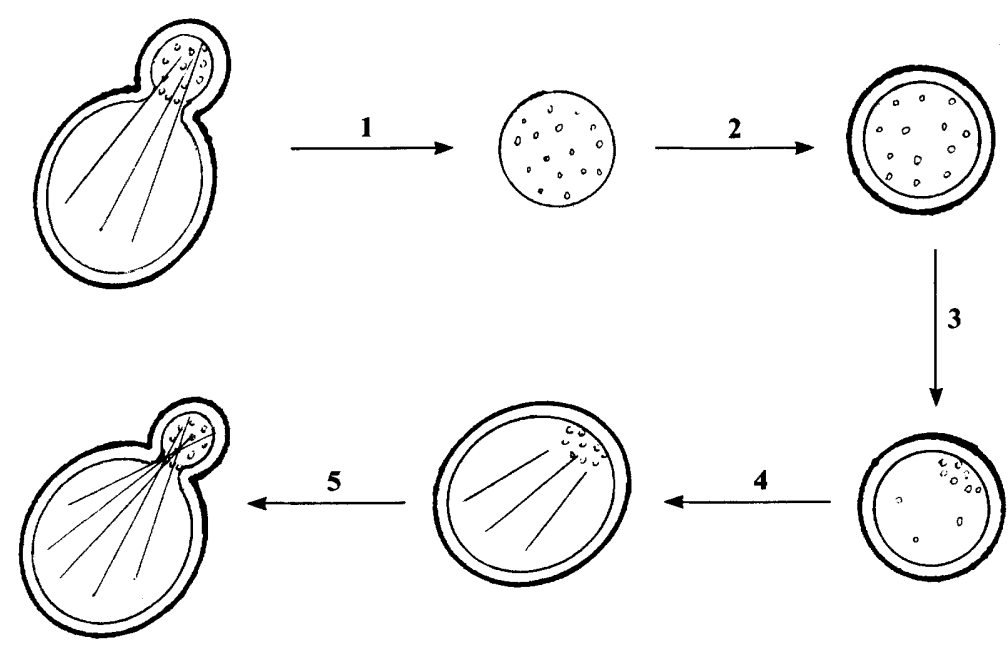

Fig. 2. Schematic diagram showing the rearrangement of the actin cytoskeleton during protoplasting, wall regeneration and protoplast-to-cell reversion. 1, Protoplasting; 2, cell wall regeneration; 3-5, reversion of the walled protoplast to a cell [assembly of actin dots (3), appearance of actin cables (4), bud emergence (5)]. completion of wall regeneration. The distribution of fluorescent actin dots under the surface of the growing protoplast remained unchanged (Fig. $1 \mathrm{~g}$ ). Actin cables were not seen.

\section{Actin cytoskeleton in protoplasts reverting to cells}

Protoplasts isolated from gelatin after $5 \mathrm{~h}$ incubation reverted to cells after cultivation in liquid regeneration medium for $14 \mathrm{~h}$. They produced a heterogeneous population, including regenerated non-budding protoplasts (Fig. $1 h, i$ ), revertants at different stages of reversion to cells (Fig. $1 j-m$ ) and normal reverted cells.

The regenerated budless protoplasts contained actin dots distributed in a more or less regular pattern (Fig. $1 \mathrm{~g}$, $h$ ). In a minor part of this population, the fluorescent dots were accumulated to a patch (Fig. 1 $i$ ) from which fluorescent cables frequently extended into the cytoplasm.

A major part of the population was composed of regenerated protoplasts with buds (Fig. $1 j$ ) that contained actin dots (Fig. $1 k$ ). In the other parts of the protoplasts, fluorescence was found only occasionally (Fig. $1 k-m$ ). The neck of the bud showed an actin ring often masked by accumulated dots. The most conspicuous features in reverting protoplasts, however, were the restored actin cables seen near the protoplast perimeter organized approximately along the long axis and extending far into the bud interior (Fig. $1 l, m$ ). The amount of cytoplasmic actin cables in revertants seemed higher than in the initial cells.

In celis derived from reverted protoplasts, the pattern of actin distribution did not differ from that of the original cells.

Electron microscopy of frozen and fractured reverting protoplasts showed the presence of complete cell walls in both the regenerated protoplasts and the subsequent reverted cells (not shown). The last stage of the cell cycle, i.e. cytokinesis and septum formation, could be seen. The septum between the regenerated protoplast and its 'daughter' cell had the same thickness as the lateral wall of the protoplast or the wall of the arising cell.

Electron microscopy failed to identify structures corresponding to the actin cables or actin dots visualized by fluorescence in regenerating and reverting protoplasts.

\section{Discussion}

Changes in the actin cytoskeleton during protoplasting

This study, as well as the earlier results of Kobori et al. (1989), demonstrated that the removal of the cell wall of $S$. cerevisiae and the alteration in cell shape result in a profound change in the distribution of the actin cytoskeleton and in its rearrangement (shown diagrammatically in Fig. 2). This evidently gives the same phenotype as mutation in the actin gene or in genes encoding the actin-associated proteins (Novick \& Botstein, 1985; Drubin et al., 1988; Liu \& Bretscher, 1989; Adams et al., 1989; Amatruda et al., 1990; Haarer et al., 1990; Johnston et al., 1991).

A higher-than-usual amount of actin dots in fresh protoplasts could indicate that they originate from disrupted actin cables. Their superficial localization indicates that the dots are lying close to the inner surface of the plasma membrane or are in direct contact with it. It can be assumed that a change in shape during protoplasting or a long incubation with lytic enzymes leads to restructuring of the plasma membrane. This process may be associated with rearrangement and redistribution of actin dots. This assumption offers an 
interesting area of investigation into the involvement of the associated proteins in interactions between actin and the plasma membrane.

\section{Actin and wall formation}

Adams \& Pringle (1984) and Kilmartin \& Adams (1984) found a correlation between the regions of surface growth in yeast cells and the areas showing increased concentrations of actin dots. Based on this correlation they proposed a role for actin in the localization of surface growth. With the use of a model system of temperature-sensitive actin mutants this notion was confirmed by Novick \& Botstein (1985). In regenerating yeast cell protoplasts, the synthesis of a new cell wall takes place all over the surface (Nečas \& Kopecká, 1969; Nečas et al., 1970). The even distribution of actin dots found under the whole protoplast surface during this process suggests that the dots participate in the activation of the synthesis of the new cell wall. Their role in the formation of the cell wall was concluded by Kobori et al. (1989) from experiments with Schizosaccharomyces pombe protoplasts.

What is the nature of the dots and on what principle would they operate during the cell wall synthesis? Ultrathin sections of $S$. cerevisisae cells have so far failed to reveal structures analogous to the dots at the ultrastructural level. Filasomes found in Sch. pombe (Kanbe et al., 1989) are too small to be correlated with the dots, but their topology is very similar to that of the dots. It may be speculated that, after decoration with antibodies, filasomes could be visualized by fluorescence microscopy. In areas of intensive wall synthesis, however, secretory vesicles containing wall glycoproteins are found. It is possible that, before fusing with the plasma membrane, the vesicles make contact with actin that, in turn, would participate in exocytosis.

The accumulated vesicles, the inhibition of invertase secretion and the delocalization of chitin synthesis, which all appear after the actin gene is made inactive (Novick \& Botstein, 1985), are findings that could give support to this concept.

\section{Actin and reversion of walled protoplasts}

Translocation of dots to the bud and the septum region in reverting protoplasts was identical with that in dividing cells (Fig. 2). It was of interest to investigate if there was any temporal or spatial correlation between repair of the actin cytoskeleton and protoplast-to-cell reversion. Such a correlation was found : actin cables were demonstrated in the cytoplasm of protoplasts shortly before bud emergence and persisted during budding. By visual comparisons they were more numerous and denser than the actin cables observed in parental cells. Their role is most probably related to the vectorial transport of secretory vesicles to the synthesizing cell wall, and to assembly of the bud (Drubin et al., 1988). The process of protoplasting leads to the loss of polarity; the re-establishment of polarity is accomplished by the reappearance of actin cables and is a prerequisite of the vectorial character of wall formation which, eventually, produces a normal cell.

The renewal of morphogenesis in regenerated yeast protoplasts thus does not depend only on completed regeneration of the cell wall; apparently, it must be preceded by repair of the actin cytoskeleton in concert with other cytoskeletal components.

The authors wish to thank Professor H. J. Phaff, Department of Food Science and Technology, University of California, Davis, USA, for the kind gift of rhodamine phalloidin, and Professor D. Botstein and Dr P. Grisaf, MIT, Cambridge, USA, for donation of the yeast strain. They also appreciate the technical assistance of Mrs V. Ramíková, Mrs J. Drápalová, Mr M. Holubáŕ and Mr J. Krobauer.

\section{References}

Adams, A. E. M. \& Pringle, J. R. (1984). Relationship of actin and tubulin distribution to bud growth in wild-type and morphogenetic mutant Saccharomyces cerevisiae. Journal of Cell Biology 98, 934-945.

Adams, A. E. M., Botstein, D. \& Drubin, D. G. (1989). A yeast actinbinding protein is encoded by $S A C 6$, a gene found by suppression of an actin mutation. Science 243, 231-233.

amatruda, J. F., Vannon, J. F., Tachell, K., Hug, C. H. \& Cooper, J. A. (1990). Disruption of the actin cytoskeleton in yeast capping protein mutants. Nature, London 344, 352-354.

DRUBIN, D. G. (1991). Development of cell polarity in budding yeast. Cell 65, 1093-1096.

Drubin, D. G., Miller, K. G. \& Botstein, D. (1988). Yeast actinbinding proteins: evidence for a role in morphogenesis. Journal of Cell Biology 107, 2551-2561.

HaArer, B. K., Lillie, S. H., Adams, A. E. M., Magdolen, V., Brandlow, W. \& Brown, S. S. (1990). Purification of profilin from Saccharomyces cerevisiae and analysis of profilin deficient cells. Journal of Cell Biology 110, 105-114.

Johnston, G. C., Prendergast, J. A. \& Singer, R. A. (1991). The Saccharomyces cerevisiae MYO2 gene encodes an essential myosin for vectorial transport of vesicles. Journal of Cell Biology 113, 539551 .

Kanbe, T., Kobayashi, I. \& Tanaka, K. (1989). Dynamics of cytoplasmic organelles in the fission yeast Schizosaccharomyces pombe: three-dimensional reconstruction from serial sections. Journal of Cell Science 94, 647-656.

Kelleti, T., Szabolzi, G., Lenvai, A. \& Garzo, T. (1954). Untersuchungen über die lebensfähigen Eiweisskörper von Saccharomyces cerevisiae. Die Regeneration in sterilen Filtrat von zerstorten Hefezellen. Acta Scientifica Academiae Scientiarum Hungaricae 5, 213-217.

Kilmartin, J. V. \& Adams, A. E. M. (1984). Structural rearrangements of tubulin and actin during the cell cycle of the yeast Saccharomyces. Journal of Cell Biology 98, 922-933.

Kobori, H., Yamada, N., TaKi, A. \& Osumi, M. (1989). Actin is associated with the formation of the cell wall in reverting protoplasts of the fission yeast Schizosaccharomyces pombe: Journal of Cell Science 94, 635-646. 
KOPECKÁ, M. \& KREGER, D. R. (1986). Assembly of microfibrils in vivo and in vitro from $(1 \rightarrow 3)-\beta$-D-glucan synthesized by protoplasts of Saccharomyces cerevisiae. Archives of Microbiology 143, 387-395.

LIU, H. \& BRETSCHER, A. (1989). Disruption of the single tropomyosin gene in yeasts results in the disappearance of actin cables from the cytoskeleton. Cell 57, 233-242.

MOOR, H. \& MÜHLETHALER, K. (1963). Fine structure in frozen-etched yeast cells. Journal of Cell Biology 17, 609-628.

NEČAS, O. (1961). Physical conditions as important factors for the regeneration of naked yeast protoplasts. Nature, London 192, 580581.

NeČAS, O. \& KoPECKÁ, M. (1969). Synthesis of the fibrillar component of regenerating cell wall in yeast protoplasts. Antonie van Leeuwenhoek 35 (Suppl.), 87-88.

NeČas, O. \& Svoboda, A. (1981). Morphogenesis in protoplasts. In Yeast Cell Envelopes: Biochemistry, Biophysics and Ultrastructure, vol.
2, pp. 105-128. Edited by W. N. Arnold. Boca Raton, Florida : CRC Press.

NeČAs, O. \& Svoboda, A. (1985). Cell wall regeneration and protoplast reversion. In Fungal Protoplasts, pp. 115-133. Edited by J. F. Peberdy \& L. Ferenczy. New York: Marcel Dekker.

Nečas, O., SošKa, J., Kopecká, M. \& ReICH, J. (1970). Application of ${ }^{3} \mathrm{H}$-glucose in the study of cell wall synthesis in yeast protoplasts. In Proceedings of the 2nd International Symposium on Yeast Protoplasts, Brno, pp. 203-209. Edited by O, Nečas \& A. Svoboda. Brno: J. E. Purkynè University.

Novick, P. \& BotsteIn, D. (1985). Phenotypic analysis of temperaturesensitive yeast actin mutants. Cell 40, 405-416.

Pringle, J. R., Preston, R. A., Adams, A. E. M., Stearns, T., Drubin, D. G., HaArer, B. K. \& Jones, E. W. (1989). Fluorescence microscopy methods for yeast. Methods in Cell Biology 31, 357435 . 